\title{
INSTRUCTORS' COMPETENCE FOR ENHANCING QUALITY OF IN-HOUSE TRAINING IN MARITIME EDUCATION
}

\author{
Dmitrijs Semjonovs \\ Aleksejs Bogdaņecs \\ Novikontas Research, Latvia \\ Manuel Joaquín Fernández González \\ University of Latvia, Latvia
}

\begin{abstract}
Improving instructors' competence will enhance quality of maritime in-house training (IHT). The research question of this study was: what are the main features of a competent IHT instructor? A mixed-method study using interviews and a questionnaire was conducted among three groups of respondents: 1) safety managers, vetting and technical managers; 2) IHT instructors, and 3) seafarers (including masters, chief engineers, officers and ratings). Professionals of the field were involved in interpretation of results and in elaboration of the recommendations for enhancing quality of IHT.
\end{abstract}

Keywords: In-house training, instructor competence, maritime training, vocational education and training

\section{Introduction}

Enhancing attractiveness of vocational education and training (VET) is a topical priority in Europe, especially since the Copenhagen declaration (EC, 2002). In the Bruges Communiqué, the European Ministers for VET stressed the necessity of "increasing public awareness of the possibilities which VET offers" (EC, 2010:8). A "prerequisite for raising the quality of VET provision is attached to the teachers and instructors, who, just as the curriculum, need up-todate knowledge and teaching skills (Keller Lauritzen et al., 2014:55).

In this general context, maritime education and training (MET) is not an exception. Recent European policy documents address seafarer' training (EU, $2005 ; 2008)$. This study addresses the specific situation in the field of in-house training (IHT). IHT is the professional short-term training the seafarers should receive before going on board the vessel, and it is not prescribed by Standards of Training, Certification and Watchkeeping for Seafarers (STCW) (IMO, 2011). IHT can be compared to workplace learning in ashore enterprises (ReferNet Latvia, 2014). IHT helps new seafarers to familiarize with work and helps professional development of experienced ones. Quality of IHT is also required by ship owners/managers. Moreover, IHT improves attitude towards safety, minimizing further expenses related to health, environment and ship protection. IHT implementation faces a number of problems: participants' lack of time, 
difficulties of organization, high costs etc. One of the main problems is the inadequacy of IHT contents and methods to the needs of diverse generations of trainees (Strauss \& Howe, 1991). Elder generations esteem that they possess already the necessary knowledge and skills; and for young generations the IHT methods seem old-fashioned, and the format of the training is not attractive.

What are the best solutions to these problems? New elements of IHT are necessary, e.g., leadership, basic office skills, "soft skills" (Dearsley, 2013). However, maritime lecturers remain the "change agents" (Zade, 2003). There is still a gap of literature regarding the necessary competences for VET instructors, and even more in the specific field of MET, whose standard (IMO, 2011) focuses on seafarers' competences, not on instructors.

This study addresses instructors' competence for enhancing quality of IHT. The research question was: what are the main characteristics of a competent IHT instructor? A mixed-design study using quantitative and qualitative methods was conducted in spring 2014 among: 1) safety managers, vetting and technical managers; 2) IHT instructors, and 3) seafarers (including masters, chief engineers, officers and ratings).

\section{Theoretical background}

Vocational education (VE) and vocational training (VT) have different goals. The general goal of VET is to develop vocational performance, a combination of vocational competence and workplace effort (Klotz et al., 2014). To enhance vocational competence and workplace effort it is essential to develop a vocational identity and workplace identity. The main difference between VE and VT is what kind of identity they seek to develop: the development of a vocational identity is a key aspect of VE, but VT is a strong instrument for the development of workplace identity (Klotz et al., 2014).

Differences between instructors and vocational educators (teachers) are also quite evident. They have distinct recruiting and education processes. "While teachers receive their education at universities ... instructors are promoted within the company after professional experience; their pedagogical qualifications are often quite limited" (Harteis et al., 2014:407). This difference is reflected in the way they organize the learning processes, and in their diverse professional development needs: it is necessary "to improve teachers' knowledge of work practices on the one hand and instructors' general pedagogical skills and competences on the other" (EC, 2010:8).

As regards MET, the process of differentiation between maritime education and maritime training (MT) is quite recent. Around 1950 MET used to be just MT. It happened on shipboard, it was oriented to develop young seafarers' "know how", and it had little interaction with the national education and training system. Some years later, more sophisticated ships appeared and higher 
qualifications were needed. MT became MET, higher admission requirements were introduced and the study program was modified.

This research is based on the understanding of competence as a dynamic combination of knowledge, skill, attitudes and values (EU, 2009); we considered also the concept of competences developed by J. Erpenbeck and L. von Rosenstiel (2007), who defined competence as behaviour that focuses on "responsibility" and includes professional-methodical, social-communicative, personal and activity-oriented sub-competences; and also the concept of competence for VET instructor developed in the Framework for VET Professions (Volmari et al., 2009) that describes operational and strategic dimensions in instructors' competence: operational dimension operates through administration and training areas, and strategic dimension -through networking activities and development, and quality assurance.

\section{Methodology}

The questionnaire "Instructors' competence for enhancing quality of inhouse training" was used for collecting quantitative data. It included 20 items grouped in 2 sections. In the first one was based on an international validated instrument (Surikova et al., 2010) that contains a general set of competences of a future-oriented teacher (see Table 1). Respondents were asked to rate these competences ( $1=$ most important, $11=$ less important). In the second part a list of nine instructor's competences was elaborated on the basis of the previously mentioned works on definition of competence, and of researchers' knowledge of the field (see Table 2). Respondents were asked to evaluate them in a 5 point Likert scale. The reliability of the questionnaire was high (Cronbach's Alpha $=$ 0.829. The questionnaire included a final open question about the most relevant IHT problems and possible solutions. 105 answers were collected: 70 from seafarers (67\%), 17 from managers (16\%) and 18 from instructors (17\%). Data were analysed using software SPSS_19, using descriptive statistics, Cross tabulation, Chi-square and Cronbach alpha tests.

Qualitative data were collected through semi-structured interviews for exploration of the context of IHT. Three main topics were investigated: 1) what makes IHT courses necessary? 2) where is the main problem in IHT? and 3) what are the best solutions for this problem? Eight interviews were conducted, two with managers, two with instructors and four with seafarers. The average time of each interview was 30 minutes, and they were recorded in audio and/or video format. The 8 interviews (fully transcribed) and the 76 written answers to the open question of the questionnaire were included in the qualitative analysis. Data were imported into the AQUAD_7 software package for improving reliability of analysis and interpretation (Cohen, 2007). Data coding was done by two researchers working simultaneously: researchers read the answers, looked for units of meaning (phrases and short paragraphs) that 
expressed the most important aspects and problems of IHT and their relation with instructors' competence. Unities of meaning were labelled using a system of codes that was partly the same that was used in the questionnaire, for facilitating triangulation of results, and partly developed from the new relevant topics that emerged in respondents' answers.

\section{Results}

We present the results of both sections of the questionnaire successively, illustrating them with some comments drawn from the interviews and the open answers included in the questionnaire, following a phenomenological interpretative approach (Smith et al., 2009).

General competences of a future-oriented IHT instructor. After data cleaning, 46 answers were retained for analysis. Three rating levels were used to facilitate comparison: high ranked (from $1^{\text {st }}$ to $3^{\text {rd }}$ ), middle ranked (from $4^{\text {th }}$ to $8^{\text {th }}$ ) and low ranked (from $9^{\text {th }}$ to $11^{\text {th }}$ ). The most significant results were highlighted in bold (see Table 1).

Table 1. Ranking of the main general competences of IHT instructor

\begin{tabular}{|c|c|c|c|}
\hline Criteria Ranking: & High & Middle & Low \\
\hline 1.1. Instructor likes his work & $\begin{array}{c}28 \\
61 \%\end{array}$ & $\begin{array}{c}16 \\
35 \%\end{array}$ & $\begin{array}{c}2 \\
4 \%\end{array}$ \\
\hline $\begin{array}{l}\text { 1.2. Instructor chooses interesting contents, adapted to the needs } \\
\text { and abilities of seafarers, and has a logical and flexible plan }\end{array}$ & $\begin{array}{c}36 \\
78 \% \\
\end{array}$ & $\begin{array}{c}6 \\
6 \\
13 \%\end{array}$ & $\begin{array}{c}4 \\
9 \% \\
\end{array}$ \\
\hline $\begin{array}{l}\text { 1.3. Instructor speaks clearly and interestingly, has good } \\
\text { communication with seafarers }\end{array}$ & $\begin{array}{c}35 \\
76 \%\end{array}$ & $\begin{array}{c}8 \\
17 \%\end{array}$ & $\begin{array}{c}3 \\
7 \%\end{array}$ \\
\hline $\begin{array}{l}\text { 1.4. Instructor follows the development of students, is available } \\
\text { for consultations, is concerned with students' development }\end{array}$ & $\begin{array}{c}23 \\
50 \%\end{array}$ & $\begin{array}{c}20 \\
43 \%\end{array}$ & $\begin{array}{c}3 \\
7 \%\end{array}$ \\
\hline $\begin{array}{l}\text { 1.5. Courses are interesting because instructor uses diversified } \\
\text { methodology according to the needs of course participants }\end{array}$ & $\begin{array}{c}22 \\
48 \%\end{array}$ & $\begin{array}{c}23 \\
50 \%\end{array}$ & $\begin{array}{c}1 \\
2 \%\end{array}$ \\
\hline $\begin{array}{l}\text { 1.6. Instructor can create his own presentations and diverse } \\
\text { material for the course }\end{array}$ & $\begin{array}{c}13 \\
28 \%\end{array}$ & $\begin{array}{c}26 \\
57 \%\end{array}$ & $\begin{array}{c}7 \\
15 \%\end{array}$ \\
\hline $\begin{array}{l}\text { 1.7. Instructor gives frequent feedback, and emphasizes on } \\
\text { participants' strengths and possibilities for improvement }\end{array}$ & $\begin{array}{c}18 \\
39 \%\end{array}$ & $\begin{array}{c}22 \\
48 \%\end{array}$ & $\begin{array}{c}6 \\
13 \%\end{array}$ \\
\hline $\begin{array}{l}\text { 1.8. Instructor is aware and has practical experience on the } \\
\text { topics of the course on national and international level }\end{array}$ & $\begin{array}{c}27 \\
59 \%\end{array}$ & $\begin{array}{c}17 \\
37 \%\end{array}$ & $\begin{array}{c}2 \\
4 \%\end{array}$ \\
\hline $\begin{array}{l}\text { 1.9. Instructor looks for new ways of teaching, is open to } \\
\text { suggestions, reflects on his own practice }\end{array}$ & $\begin{array}{c}20 \\
43 \%\end{array}$ & $\begin{array}{c}18 \\
39 \%\end{array}$ & $\begin{array}{c}8 \\
17 \%\end{array}$ \\
\hline $\begin{array}{l}\text { 1.10. Instructor involves course participants in research projects } \\
\text { (helps seafarers to reflect) }\end{array}$ & $\begin{array}{c}15 \\
33 \%\end{array}$ & $\begin{array}{c}15 \\
33 \%\end{array}$ & $\begin{array}{c}16 \\
35 \%\end{array}$ \\
\hline $\begin{array}{l}\text { 1.11. Instructor uses Internet and new technologies for } \\
\text { improving learning }\end{array}$ & $\begin{array}{c}21 \\
46 \%\end{array}$ & $\begin{array}{c}12 \\
26 \%\end{array}$ & $\begin{array}{c}13 \\
28 \%\end{array}$ \\
\hline
\end{tabular}


The competence Presenting interesting content [1.2] was rated as high by $78 \%$ of respondents $(\mathrm{N}=36)$. This tendency was confirmed during the interviews. For example, a manager said that "IHT should allow trainee to react in a proper, fast and efficient way" (respondent No 82), and several seafarers stressed that "training instructors should be at least in one step with industry" (No 13).

The competence Good communication [1.3] was rated as high by $76 \%$ of respondents $(\mathrm{N}=35)$. In their open answers, managers stressed that "instructor shall always ensure that the link between him and students is not lost" (No 8), and that "exchange of information between instructor and students is also very important!" (No 24). Some seafarers said that "some instructors' lessons are very boring due to their monotone and chaotic speech" (No 22).

The criteria Instructor likes his work [1.1] was rated as high by $68 \%$ of respondents $(\mathrm{N}=28)$. It should be noted that this criteria was rated as the most important competence (first rank) most often $(\mathrm{N}=15)$, followed by Good communication $(\mathrm{N}=14)$ and Presenting interesting content $(\mathrm{N}=13)$. However, in the interviews and open answers this aspect appeared rarely.

International practical experience [1.8.] was rated high by $59 \%$ of respondents $(\mathrm{N}=27)$. Reflecting in past experience, a seafarer stated that "some instructors were absolutely unaware about conditions and possible risks on board of vessels" (No 51). Managers acknowledged that "It's a great idea to use the real working seafarers as instructors while they are on vacation ashore" (No 84).

Several criteria related to the use of modern pedagogical means process had a contrasted distribution of ratings. One third of respondents rated the criteria Involvement in research projects [1.10] as high, one third middle and one third low. This is the only case with such a big contrast between respondents. Opinions were also shared regarding the criteria Use of diversified methodology [1.5]: $48 \%$ of respondents $(\mathrm{N}=22)$ rated it as high and $50 \%(\mathrm{~N}=23)$ as middle (only $2 \%$ as low). Some expressions can illustrate the thoughts of respondents: "Everyone can't be an instructor/teacher. It doesn't matter how good (professional) he is or was on board the vessel in his position" (No 22).

Importance of instructors' skills and attitudes. 95 answers were retained for analysis. All items had a mode of 4 or 5 . The most significant results were highlighted in bold (see Table 2).

Four items had a Mode of 5. The most important aspect was instructors' Knowledge of the topic [2.1] $(\mathrm{M}=4.65 ; \mathrm{SD}=0.71)$. When this aspect is missing, seafarers are deceived: based on his own experience, a seafarer found inacceptable that "the instructor did not possess either deep theoretical knowledge of the subject or enough practical experience" (No 88).

Balance theory/practice [2.6] was also important for most of respondents $(\mathrm{M}=4.32 ; \mathrm{SD}=0.87)$ : "Practical and theoretical time should be balanced" (No 67). Instructors should also make a good initial evaluation in order to Adapt the 
contents of the training to the real needs of the seafarer $(\mathrm{M}=4.25 ; \mathrm{SD}=0.76)$. Only two items had a Mean fewer than 4, and they were related to the new pedagogical tendencies. The criteria Instructor involves seafarers in practical organization of the courses [2.4] got the lowest rate $(\mathrm{M}=3.88 ; \mathrm{SD}=0.90)$.

Table 2. Importance of instructors' skills and attitudes

\begin{tabular}{|l|l|l|l|}
\hline Criteria & Mode & Mean & SD \\
\hline 2.1. Instructor has good and up-dated knowledge of the topic & 5 & $\mathbf{4 , 6 5}$ & $\mathbf{0 , 7 1}$ \\
\hline $\begin{array}{l}\text { 2.2. Instructor has recent experience working in the topic } \\
\begin{array}{l}\text { 2.3. The professional status of the instructor is higher than the } \\
\text { trainees. }\end{array}\end{array}$ & 4 & 4,16 & 0,82 \\
\hline $\begin{array}{l}\text { 2.4. Instructor involves seafarers in the organization of the } \\
\text { training }\end{array}$ & 4 & $\mathbf{3 , 8 0}$ & $\mathbf{1 , 1 1}$ \\
\hline $\begin{array}{l}\text { 2.5. Instructor involves seafarers in practical exercises } \\
\text { 2.6. Instructor finds a good balance between theory and practice }\end{array}$ & 5 & 4,13 & 0,90 \\
\hline $\begin{array}{l}\text { 2.7. Instructor makes an initial evaluation for adapting the } \\
\text { contents }\end{array}$ & 4 & 4,25 & 0,96 \\
\hline $\begin{array}{l}\text { 2.8. The instructor develops his own teaching skills } \\
\text { 2.9. The instructor reaches the objectives efficiently and fast }\end{array}$ & 5 & 4,25 & 0,84 \\
\hline
\end{tabular}

Summarizing, the ideal IHT instructor: 1) has good knowledge of the topic in one step with industry, and delivers interesting content with a good balance between theory and practice; 2 ) is a real professional with practical experience, a working seafarer; 3) has good communication skills and presents information attractively; creates a link with students, and provokes exchange of information between instructor and students; and 4) likes his work, cares about seafarers and develops his/her own teaching styles. Some aspects of IHT instructors' work that are related to the new pedagogical tendencies do not make unanimity or are low rated.

\section{Discussion}

This study shed light on the specificity of vocational education settings regarding instructors' competence. In the previously mentioned study (Surikova et al., 2010), which used the same set of competences as the present study, it was found that the highest rated competences among Latvian professors as teacher trainers in university were Professional identity [1.1], Development of methodological strategies [1.5] and Construction of approaches to educational research [1.10]. In maritime education, the Knowledge of the contents [1.2] and the Quality of the communication [1.3] are more important. This could be explained by mandatory requirements established by STCW, which gives strict rules about contents to be delivered, and even about the ways of delivering it: there is not much room for focussing on educational approaches and strategies. 
The finding regarding the necessity of employing instructors who are real professionals with practical experience, working seafarers, is consistent with recent research. The necessity of involving "teachers from the real world" in VET was recently stressed by academics: "we need to bring the world of education and the world of business closer together. Teachers from the "real world" need to be more visible in the education systems". (Keller Lauritzen et al., 2014:55). In MET also, it is recognized that the most important role of the vocational system is to enhance competences based on the experience acquired during the practice period on the board of the ship (Stan \& Buzbuchi, 2012).

Also regarding the finding that IHT instructors should have a good knowledge of the topic in one step with industry has an echo in recent research on VET. In the mentioned report is stated that "VET teachers need to have sufficient skills and knowledge to undertake teaching that is in line with the times" (Keller Lauritzen et al., 2014:54). The Bruges communiquéé proposed to enhance traineeships for VET teachers in enterprises as one of the short term deliverables for 2011-2014 (EC, 2010).

As regards the need of improving MET lecturers' pedagogical skills and use of innovative methods and teaching styles, MET is still a field where the reluctance to change is present. Long-serving lecturers tend to be reluctant to accept and introduce changes to subjects that they may have taught for decades. The resistance to change appears also in the "preference of some maritime lecturers to perpetuate outdated syllabi contents. Such an attitude is detrimental to the updating of syllabi" (Zade, 2003:39).

\section{Recommendations}

A focus group discussion was organized with 25 representatives of relevant companies involved in organization and implementation of IHT in September 2014 to improve the relevance of discussion and recommendations of this study. It was introduced by a presentation of the results obtained in this study. We reproduce here a summary of their recommendations:

1) "Giving sense to the training", enhancing awareness of the usefulness of IHT: in general, to change from "must do" to "usefulness" approach; to show why training is needed with concrete examples; to keep eyes open to industry requirements; to give updated, fresh, qualitative information; to simulate emergency situations; to balance theory $(30 \%)$ and practice $(70 \%)$; to use an international approach.

2) "Improving communication skills" in teaching-learning process: to share experiences using (funny) stories from real life; to foster twoway communication; to make small groups, giving frequent feedback; to make training friendly (welcome drinks served by the lector the first day for breaking ice, usage of attractive material, not only PowerPoint presentations). 
3) "Innovation in teaching" using new pedagogical resources: to invite instructors who have interesting teaching style; to invite good lectors from outside to train teachers; to shift instructors between courses for diversity; to use company specific materials (case studies); to use webinars, multimedia materials (TED talks, internet...); to use outside-class learning.

4) “Adapting to students' needs": to make initial assessment and to apply different programs according to it; to elaborate new programs when necessary; to involve students (instructor should not talk too much, but participants should do more); to make trainees do training by themselves, asking them to "teach" someone else.

The practical implications of this research for training managers, instructors, and directors of MET are quite evident. The findings of this study provide useful information about new possibilities of development of the professional field of IHT. The results shows that competent IHT instructors should not rely only on their knowledge and experience of their topic; they need also to improve their practices as trainers, giving sense to their teaching, improving their communication skills and having the courage to go away from barriers and to adopt a creative approach in the organization of the learning processes. This study opens also new lines for future research on the development of vocational education teachers' competence.

\section{References}

Cohen, L et al. (2007). Research methods in Education (7th edition).USA: Routledge.

Dearsley, D. (2013). Maritime Career Path Mapping 2013 Update. A rapport for the European transport workers' federation (ETF) and the European community shipowners' associations (ECSA). http://www.ecsa.eu/images/files/Rapport_Maritime_Career.pdf [accessed on 11.02.2015]

Erpenbeck, J. \& Rosenstiel, L. von (eds.) (2007). Handbuch Kompetenzmessung: Erkennen, verstehen und bewerten von Kompetenzen in der betrieblichen, pädagogischen und psychologischen Praxis. Stuttgart: Schäffer-Poeschel

EC - European Commission (2002). The Copenhagen Declaration: Declaration of the European Ministers of Vocational Education and Training, and the European Commission on enhanced European cooperation in vocational education and training. http://ec.europa.eu/ education/policy/vocational-policy/doc/copenhagen-declaration_en.pdf [accessed on 11.02.2015]

EC - European Commission (2010). The Bruges Communiqué on enhanced European Cooperation in Vocational Education and Training for the period 2011-2020. http://ec.europa.eu/education/policy/vocational-policy/doc/brugescom_en.pdf [accessed on 11.02.2015]

EU - European Union (2005). Opinion of the European Economic and Social Committee on the 'Promotion of sea transport and the recruitment and training of seafarers' (2005/C 157/05) http://eur-lex.europa.eu/legal-content/EN/TXT/PDF/?uri=CELEX:52004 IE1631\& from=EN [accessed on 11.02.2015]

EU - European Union (2008). Directive 2008/106/EC of the European Parliament and of the Council of 19 November 2008 on the minimum level of training of seafarers (recast). 
http://eur-lex.europa.eu/LexUriServ/LexUriServ.do?uri=OJ\%3AL\%3A2008\%3A323\%3A 0033\%3A0061\%3AEN\%3APDF [accessed on 11.02.2015]

EU - European Union (2009). Glossary of the recommendation of the European Parliament and of the Council of 23 April 2008 on the establishment of the European Qualifications Framework for lifelong learning. http:/www.eucen.eu/EQFpro/GeneralDocs/ FilesFeb09/GLOSSARY.pdf [accessed on 11.02.2015]

Harteis, C., Billett, S., \& Gruber, H (2014). International Handbook of Research in Professional and Practice-based Learning. London: Springer.

IMO (International Maritime Organization) (2011). International Convention on Standards of Training Certification and Watchkeeping for Seafarers -STCW. London: IMO. ISBN 978-92-801-1528-4

Keller Lauritzen J.R., Andersen, T., Secher J.E.O., Olsen, S., \& Fuglsang Østergaard, S.M. (2014). Preparation of the European Business Forum on Vocational Training: Final report. Copenhagen: Danish Technological Institute. http://ec.europa.eu/education/library/ study/2014/business-forum_en.pdf [accessed on 11.02.2015]

Klotz, V.K., Billett, S., \& Winther, E. (2014). Promoting workforce excellence: formation and relevance of vocational identity for vocational educational training. Empirical Research in Vocational Education and Training 2014, 6:6. http://www.ervetjournal.com/content/6/1/6 [accessed on 11.02.2015]

ReferNet Latvia (2014). VET in Europe -Country report Latvia. Cedefop (European Centre for the Development of Vocational Training) http://www.refernet.lv/uploads/ Country_Report_LV_2014.pdf [accessed on 11.02.2015]

Smith, J.A., Flowers, P., \& Larkin, M. (2009). Interpretative Phenomenological Analysis: Theory Method and Research. London: Sage.

Stan, L.C. \& Buzbuchi, N. (2012). Considerations on Maritime Watch Keeping Officers' Vocational Training. TransNav, the International Journal on Marine Navigation and Safety of Sea Transportation, Vol. 6, No. 4, pp. 533-536

Strauss, W. and Howe, N. (1991). Generations: The History of America's Future, 1584 to 2069. New York: Morrow.

Surikova, S., Baranova, S., Fernández González, M., Maslo, I., \& Huber, G. (2010). The Development of Professors as Teacher Trainers and Their Future-Oriented Competences in Latvia.IN: Egetenmeyer, Regina and Nuissl, Ekkehard (Eds.) Teachers and Trainers in Adult and Lifelong Learning. European and Asian Perspectives, pp.199-208. Frankfurt am Main: Peter Lang Verlag, ISBN 978-3-631-61298-9

Volmari, K, Helakorpi, S., \& Frimodt, R. (Eds) (2009). Competence Framework for VET Professions. Handbook for practitioners. Sastamala (FL): Finnish National Board of Education and editors. ISBN 978-952-13-4117-5 (paperback) ISBN 978-952-13-4118-2 (pdf).

Zade, G. (2003) Thematic Network on Maritime Education, Training and Mobility of Seafarers (METNET). Final Report for Publication. Malmö, Sweden: World Maritime University. http://www.accademiamarinamercantile.it/doc/report.pdf [accessed on 11.02.2015] 